\title{
The model to predict sand production for production wells at Cuu Long basin
}

- Ta Quoc Dung

University of Technology, VNU-HCM- tqdung@hcmut.edu.vn

- Hoang Thanh Tung

Petrovietnam Drilling \& Well Services Corporation (PV Drilling)

(Manuscript Received on August 25 $5^{\text {th }}, 2014$; Manuscript Revised November 11 $1^{\text {th }}, 2014$ )

\section{ABSTRACT:}

Sand production in Sandstone reservoirs is a complex problem to Oil \& Gas companies. Many methods have used to solve this problem but these methods only have effect for the first period of production without effective in long time. Sand production causes big damages such as: producing tools corrosion in hole, separating tools corrosion at surface, formation collapse, so sand

Keywords: sand production, geomechanics, Cuu Long basin.

\section{INTRODUCTION}

Around the world, sand production phenomenon in oil wells in Miocene, Oligocene, Pliocene sandstone is not a new topic. This situation has been solved to several fields and several wells. The influences of sand production are producing tools corrosion, damaging well structure, reducing recovery factor. So this problem is the unexpected phenomenon. Furthermore, sand production will destroy safety valves causing dangerous results. Specially in offshore, it takes a long time and experience to repair tools [1]. This study proposed the basic problems of well completion in concept, role, purpose and the basic design process. The research basically defined the characteristic of formation. But result didn't give the specific conclusion of sand production. The other study [2] proposed the summary of theoretical basis of sand production phenomenon. It's based on the graded gravel curve to calculating and designing filter cartridge jammed gravels. Chosen size of gravel and filter screen to control amount of sand in oil well effectively.

All of the sand control methods have to be researched, calculated and performed most effectively production in well is always the urgent problem. Based on formation characteristic research, advantages and disadvantages of sand failure analysis and combining the advanced methods, this study introduces Production Sand Pressure Model to predict sand productivity in sedimentary reservoirs in field $X$ in Cuu Long basin.

in the first period of well completion and production. All of the others in the later period are fixes so can't supply the high recovery factor as the first period. From this study will supply the new look and the new method to control sand production in oil production, predicting sand production in sandstone reservoirs to restrict the affects of sand.

\section{FUNDAMENTAL OF SAND PRODUCTION AND SAND CONTROL}

\section{Sand production}

Sand production is the movement of certain amount of solids (sand or fines) from formation into the well. The amount of sand can be little or much (several grams) in one ton of produce fluids depending on each formation conditions.

Cause of sand production

Formation strength

Sedimentary rock formed from sedimentary material (solid particles) and cement material mounted. For young sedimentary rocks, shallow burial depth is usually less cement material mounted and low cohesion.

\section{Trang $1 / 2$}


It is the object of the sand production in oil and gas wells. Sedimentary rocks formed before, in greater depth, the quality of cement binding will decide the rock strength. There are many different types of mounting cement: mineral quartz, calcite, dolomite and clay minerals. Examining the sedimentary rocks mounted with clay minerals, the link between the solid particles is usually weak, risk of destruction; on the other hand, if the material is mounted quartz crystal, the rock strength will be very high. If the formation compressive strength is less than $1000 \mathrm{psia}$, the formation will have a very high sand production rate-usually the tertiary sediments.

\section{Stress changes around wellbore}

There are many factors that stress changes around wellbore as: production flowrate changes, the fluid viscosity in the reservoir, perforating or due to the depletion of reservoir pressure. As the production flowrate increases led to the flow velocity increases, which increases the friction between the fluid and sand, the flow will pull sand reservoir into the well. Viscosity is one of the parameters affecting the sand production. When the fluid viscosity in the reservoir increases, the friction between the sand particles will increase, which increases traction in sand particles into the well. Perforating creates compression zones around the wellbore, this compression zone has low permeability and easy to be destroyed when production flowrate fluctuations or high viscosity fluids. In the initial conditions of the reservoir, the reservoir pressure (pore pressure) is high. Effective stress is small. But after a long period of production, reservoir pressure declines, which increases the amount of effective stress. When this stress is greater than the compressive strength of the rock, it will cause formation damage which led to sand production.

\section{Formation water influx}

Most reservoir rocks are wet sticky so when formation water influx affect sand production ability. Specifically, intrusion of water causes the following effects and tends to increase the amount of sand entering the well:

- Cement dissolved: when entering the pores of rock, the water soluble cement materials, especially calcite or dolomite, which disrupts the rock stability, when flowrate changes or high-viscosity oil, it will pull sand into the well. Here is the reaction of dissolved calcite:

$$
\mathrm{CaCO}_{3}+\mathrm{H}^{+} \leftrightarrow \mathrm{Ca}^{2+}+\mathrm{HCO}^{-}
$$

- Alter the surface tension and capillary forces between solid particles: sand particles not only linked together by cement materials but also linked together by surface tension, and capillary forces, when reservoir water flows into wellbore, capillary force will be reduced led to the loosing of interconnectivity between the sand grains.

- Reduce the permeability of oil and gas: because of reduced permeability, the system tends to increase in pressure to ensure that the flowrate doesn't change, if the reduced pressure is greater than the formation strength, sand will appears.

Sand production consequences

- Accumulation of sand at the bottom of well.

- Accumulation of sand on the facilities' surface.

- Corrosion of downhole and surface equipment.

- Wellbore collapse

Introduction of Sand Production Pressure Model

Sand production pressure model is significant to production management. The result of this model notes critical pressure at which sand is produced. The result of the model is compared to the result of reservoir testing and the real result from production accompanied sand.

Sand production pressure model is calculated in associated with the knowledge of rock strength, the knowledge of rock structure, the knowledge of stress, the knowledge of rock damage, and many other attentions.

\section{Description of Sand Production Model}

\section{Impact of Stress Concentration Effects.}

This Model is based on a simple apparent strength criterion, applied to a formation element next to a circular hole. The hole could be the wellbore (for open hole completion), or a perforation (for cased hole completion). 


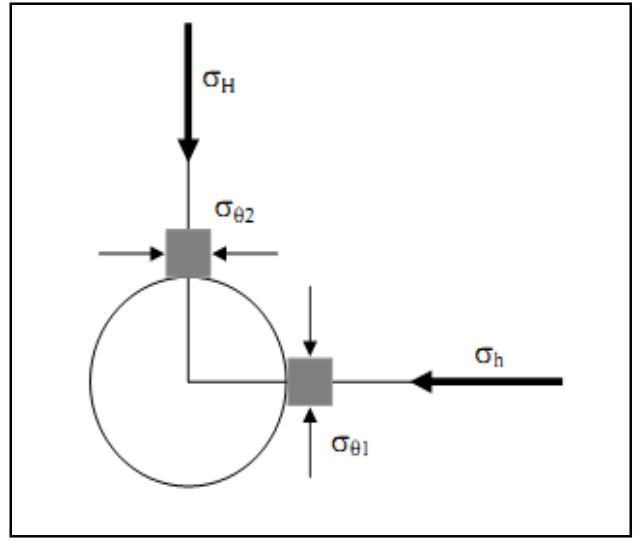

Figure 1: Tangential stresses at the wall of a hole

The hole orientation of the wellbore or the perforation is reflected in the calculation of the principal stresses perpendicular to the hole in terms of suitably transformed in situ principal stresses.

To build this Model for predicting Sand Production, we need to know when the wellbore to be failure and sand production. From figure 1 we have: [3]

$$
\begin{gathered}
\sigma_{\theta 1}=3 \sigma_{h}-\sigma_{H}-p_{w}(1-A)-A P_{o} \\
\sigma_{\theta 2}=3 \sigma_{H}-\sigma_{h}-p_{w}(1-A)-A P_{o}
\end{gathered}
$$

Where: $p_{0}$ : reservoir pressure

$\mathrm{p}_{\mathrm{w}}$ : wellbore pressure

A : is a poro-elastic constant given by:

$$
A=\frac{(1-2 v) \alpha}{1-v}
$$

$\alpha$ and $v$ are Biot's and poison ratio, respectively.

To avoid sand production the largest effective tangential stresses $\sigma_{\theta 2}-p_{w}$ should be smaller than the effective strength of the formation $\mathrm{U}$ :

$$
\sigma_{\theta 2}-p_{w} \leq U
$$

Solving the inequality (4) for Pw follows that:

$$
p_{w} \geq \frac{3 \sigma_{H}-\sigma_{h}-U}{2-A}-P_{o} \frac{A}{2-A}
$$

The critical drawdown pressure (CDP) (Critical Drawdown Pressure) is defined as the drawdown from the reservoir pressure to cause failure (and sand production) of the reservoir. Using the definition, the bottom hole pressure in the well is:

$$
p_{w}=P_{o}-C D P
$$

Introducing (5) we find the fictional relation between the reservoir pressure, Po, and CDP:

$$
P_{o}=\frac{1}{2}\left[3 \sigma_{H}-\sigma_{h}-U+C D P(2-A)\right]
$$

And:

$$
C D P=\frac{1}{2-A}\left[2 P_{o}-\left(3 \sigma_{H}-\sigma_{h}-U\right)\right]
$$

In particular the Critical Reservoir Pressure (CRP) defined as the reservoir pressure that would not tolerate any drawdown, is given by (7) for $\mathrm{CDP}=0$.

$$
C R P=\frac{3 \sigma_{H}-\sigma_{h}-U}{2}
$$

Relation of Effective Formation Strength U, to measured Strength. The collapse pressure of a called Thick-walled Cylinder Test (TWC) is used as the fundamental strength measure for unsupported boreholes perforations. The testing showed that relative to the collapse pressure of the standard specimen TWC and formation strength $U$ is:

$$
U=3.1 T W C
$$

In addition, based on well deviation well I and azimuth well $\theta$ and [4] we have:

$$
\sigma_{x}=\sigma_{H} \cos ^{2} \theta \cos ^{2} i+\sigma_{h} \sin ^{2} \theta \cos ^{2} i+\sigma_{v} \sin ^{2} i
$$

$$
\sigma_{y}=\sigma_{H} \sin ^{2} \theta+\sigma_{h} \cos ^{2} \theta
$$

$\sigma_{z}=\sigma_{H} \cos ^{2} \theta \sin ^{2} i+\sigma_{h} \sin ^{2} \theta \sin ^{2} i+\sigma_{v} \cos ^{2} i$

$$
\tau_{x y}=\frac{1}{2}\left(\sigma_{H}-\sigma_{h}\right) \sin 2 \theta \cos i
$$

\section{Trang 74}


$\tau_{x z}=\frac{1}{2} \sin 2 i\left(\sigma_{v}-\sigma_{H} \cos ^{2} \theta-\sigma_{h} \sin ^{2} \theta\right)$

$$
\tau_{z y}=\frac{1}{2}\left(\sigma_{H}-\sigma_{h}\right) \sin 2 \theta \cos i
$$

\section{IMPLEMENTATION PROCESS}

\section{Analysis of aggregate particles}

The coring and particle composition analysis are very important in choosing filter tube or gravel pack of packing method. There are two methods of particle composition analysis: using Sieve method (Sieve) and using Laser Particle Size method (LPS). LPS method is being used more and more popular with fast, accurate results, and can be performed on a small number of the core (about 1 gram).

Final results obtained from the two above methods are particle aggregate curve: classified by the percentage of weight of each solids size.

On particle aggregate curve, there are particular coefficients: $D$ is particle size in proportion to $n \%$ of particles passed through a sieve. The coefficients of aggregate particles are often used in the calculation of designing gravel pack of packing: D10 is particle size at which $10 \%$ of its weight passes through a sieve, and it's similar to D40, D50, D90 and D95. There is also Uniform Coefficient (UC): UC = D40/D90 or D10/D95.

In filter tube design, or gravel pack of packing, it's common to use mesh U.S. units instead of using inch, or $\mathrm{mm}$.

\section{Gravel options \\ Gravel shape}

- If gravel is more angular, it will reduce its permeability of gravel layer and has ability to fill up formation opening firing hole.

- $\quad$ The best gravel has rounded edges and the same size (equal). The suggested rounded edges and roundness levels are 0.6 or better.

- There are many ways of gravel pack of packing which have different porosity and permeability. For example: Cubic packing - porosity $=48 \%$, Rhomobohedral packing - porosity $=26 \%$.
- $\quad$ Should select gravel carefully before putting into well because gravel may not correct as the design sizes (due to two reasons: broken when transporting to opening shooting formation area or lack of quality management of gravel suppliers

\section{$\underline{\text { Solubility }}$}

- Gravel contains silicon was dissolved in steam with high temperature and $\mathrm{pH}$, especially $\mathrm{pH}>$ 11.

- Gravel contains bauxite is dissolved in $\mathrm{HCl}$ and HF acid but it's heat-resistant. Therefore, it should be used in high temperature wells. However, we should pay attention if silica sand system, steam will dissolve.

\section{Filter pipe options}

- $\quad$ The size of hole on the screen

- The permeability of the screen

- $\quad$ The rate of fluid through screen

- Drawdown pressure through screen

- Length of screen

- Durability of screen

- $\quad$ The hole density of screen

\section{APPLICATION}

The data was selected at E20 formation from X field in Cuu Long basin with basic information such as:

Table 1: Data at E20 formation

\begin{tabular}{|c|c|c|}
\hline \multicolumn{3}{|c|}{ E20 GOC } \\
\hline Wellbore diameter & 12.25 & in \\
\hline Depth (TVD) & 2266.34 & $\mathrm{~m}$ \\
\hline Well deviation & 52.7 & $\mathrm{deg}$ \\
\hline Well azimuth & 230.5 & $\mathrm{deg}$ \\
\hline Poisson's ratio & 0.26 & \\
\hline Reservoir pressure & 3197 & $\mathrm{psi}$ \\
\hline $\begin{array}{c}\text { Unconfined compressive } \\
\text { strength }\end{array}$ & 1870 & $\mathrm{psi}$ \\
\hline Vertical stress & 6650 & $\mathrm{psi}$ \\
\hline Min. horizontal & 4959 & $\mathrm{psi}$ \\
\hline Max. horizontal & 5207 & $\mathrm{psi}$ \\
\hline Sand grain diameter (D50) & 204.8 & $\mu \mathrm{m}$ \\
\hline
\end{tabular}

\section{Results}

The model based on the theory of formation damage is affected by pressure reduction and formation pressure. Axis $\mathrm{X}$ is Reservoir Pressure, Axis $\mathrm{Y}$ is Wellbore Pressure. The purble line is balance line where bottom-hole pressure equals reservoir pressure. This line separates the plot into two segments. The upper part demonstrates situations which related to over balance in drilling and injection, and the below part 
demonstrates what pressure drawdown and production. Failure prediction line is blue line. In example upper blue line crosses purple line at $899 \mathrm{psi}$ point. This point is critical pressure. If pressure decreases below the critical pressure, sand is produced. The failure prediction line depends on what rock strength and well completion method. Rock strength is defined by UCS value (Unconfined Compressive Strength). Based on the failure prediction line we know the value of reservoir pressure and the value of wellbore pressure which formation damage happens. The I area demonstrates production which not occupied by sand, the II area demonstrates production which occupied by sand.

The sensitivity analysis of well parameters to sand production (Figure 3)

From the input data and the pressure model, Sand Production area and NO-Sand Production area are determined correlating to each reservoir. The results of the analysis including:

- Well deviation

- Reservoir Pressure

- Unconfined compressive strength

- $\quad$ Principle stress
The results shows the effects of these parameters:

- Critical Pressure increases when uniaxial compressive stress and horizontal stress are maximum

- Critical pressure decreases when horizontal stress is minimum, vertical stress increases.

Proposing controlling sand production method by Screen gravel pack:

- This study concludes the methods to choose gravel diameter, radius of filter cartridge. The plot of graded gravel curves in the reservoir to determine the specific criteria to choose filter screen is suggested

- Summarize the theories of chosen filter cartridge, advantages of filter cartridge:

- $\quad$ Removing or filling oval space to increase well strength and controlling sand ability.

- $\quad$ Create the minimum sand tongue or non sand accumulation.

- Give minimum sand tongue or non sand accumulation

- Decreat or remove corrosion or gravel bags.

- $\quad$ Increase formation strength...

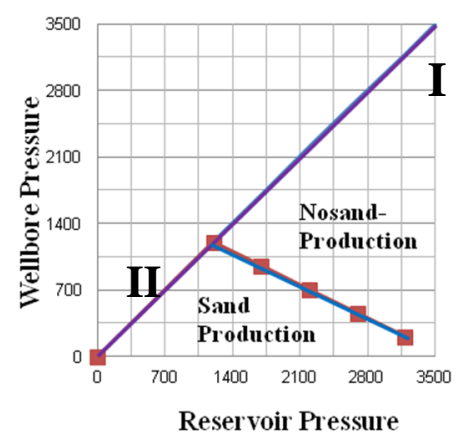

Figure 2: Failure prediction line
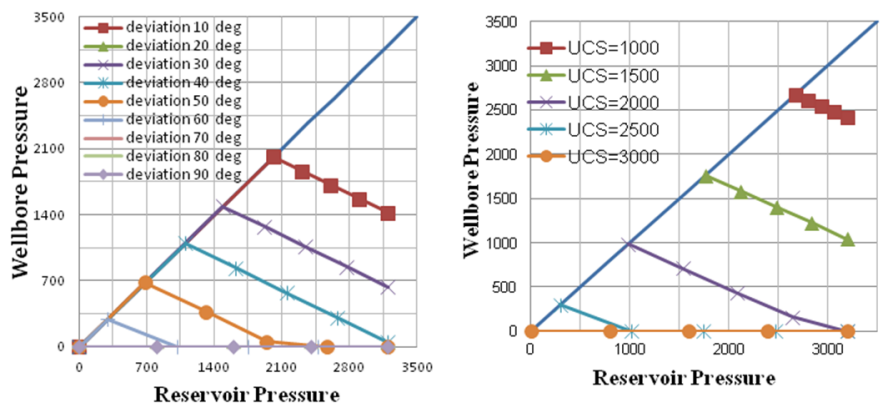

\section{Trang 76}



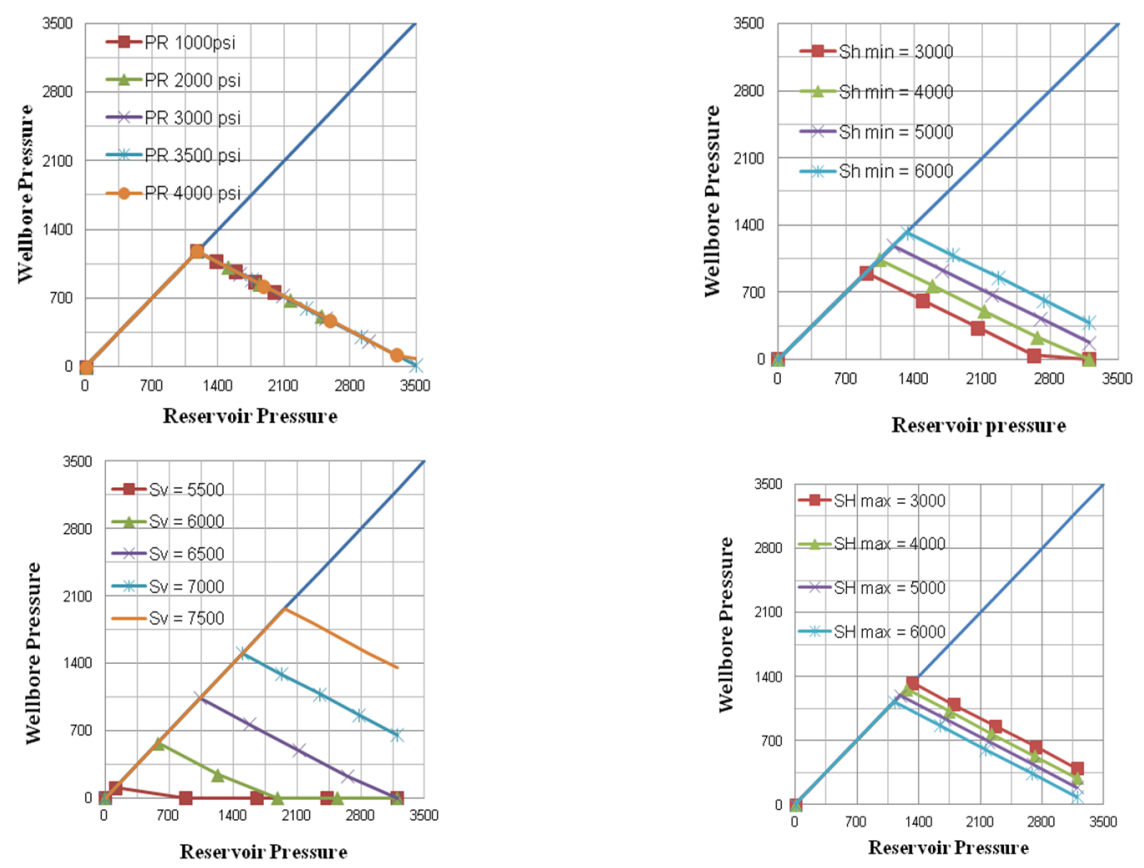

Figure 3: Failure prediction line with sensitive analysis

\section{Conclusions and recommendations}

\section{Conclusions:}

Formation characteristics, causes and consequences of sand production phenomenon:

- Sand production phenomenon is caused by cutting damage and pulling damage.

- In production, pressure reducing, water flood, changes of stress ... reducing strength and connection of the formation.

- The evaluation of the formation characteristics is important to prediction of formation damage caused by sand in well.

- Sand accumulation causes: tool corrosions, formation collapse ...

The results of research and pressure model calculation:

- Summarily sand production pressure model is an effective method to manage and restrict sand production. This model gave the pressure producing sand and reducing critical pressure. Production engineer or reservoir engineer can give solutions to manage reservoir immediately to restrict sand production and enhance production.

- Critical Pressure and Critical Drawdown Pressure in E20:

\begin{tabular}{|c|c|c|c|}
\hline Reservoir & & CDP & $\begin{array}{c}\text { Critical } \\
\text { Pressure }\end{array}$ \\
\hline E20 & & $2891 \mathrm{psi}$ & $\mathbf{8 8 9} \mathbf{p s i}$ \\
\hline
\end{tabular}

- Keeping pressure is higher than critical pressure to not produce sand.

\section{Recommendations:}

- This study did not mentinoned about design the specific filter cartridge. The next research is suggested with plot graded gravel curve to calculate and design the specific criteria of chosen filter screen

- Formation characteristic research and sand productivity research are necessary in the first period in well completion and production. Necessary to calculate sand production pressure model.

- Production correlates to critical pressure, we have to produce effectively to restrict reducing pressure below critical pressure causing formation damage by sand production.

- Manage producing regime periodically to prevent and restrict sand productivity.

- Compare sand production pressure model with petroleum software model to get the most exact result. 


\section{Mô hình dự báo sinh cát cho các giếng khai thác bồn trũng Cửu Long}

- Tạ Quốc Dũng

Trường Đại học Bách khoa, ĐHQG-HCM- tqdung@hcmut.edu.vn

- Hoàng Thanh Tùng

Công ty Dịch vụ Khoan dầu khí (PV Drilling)

\section{TÓM TÁT:}

Hiện tượng cát xuất hiện trong các giếng khai thác ở tầng cát kết là một vấn đề phức tạp cho các công ty dầu khí. Nhiều phương pháp đã được sử dụng để giải quyết vấn đề này. Tuy nhiên, những phương pháp này chỉ có hiệu lực trong giai đoạn đầu tiên của khai thác mà không có hiệu quả trong thời gian dài. Cát xuất hiện trong khai thác dầu khí

Từ khóa: Sinh cát, phá hủy đất đá.

\section{TÀI LIẸU THAM KHẢO}

[1]. N. Q. Huấn, Đánh Giá thành hệ nghiên cứu khả năng sinh cát và lựa chọn phương pháp hoàn thiện giếng phù hợp, 2011.

[2]. T. Q. Dũng, Thiết kế ống lọc có lèn sỏi khống chế cát cho giếng $\mathrm{X}$ thuộc bồn trũng Malay Thổ Chu, 2012.

[3]. S.M. Willson (BP America Inc.), Z.A. Moschovidis, J.R. Cameron ( PCM INC.) \& I.D. Palmer (BP America Inc.), "New Model for Prediting the Rate or Sand Production," SPE 78168.

[4]. R. H. P. H. A. R. R. R. E. Fjaer, Petroleum Related Rock Mechanics, 2nd Edition, Hungary: Elsevier Publications, 2008.

[5]. P. T. Tài, Nghiên cứu khả năng sinh cát cho mỏ X thuộc bồn trũng Cửu Long và đề xuất phương pháp kiểm soát cát, 2011.

[6]. P. H. Tài, Kiểm soát cát trong khai thác Dầu khí bằng ống lọc, 2007.

[7]. I.D. Palmer and N. Higgs, Higgs Technologies, and I. Ispas, K. Baksh, and K.O Krieger, BP plc, "Prediction of Sanding Using Oriented Perforatinos in a Deviated Well, and Validation in the Field," SPE 98252. gây thiệt hại lớn nhu: ăn mòn thiết bị lòng giếng, ăn mòn thiết bị bề mặt, sập lở thành giếng khai thác... Căn cứ vào đặc tính thành hệ, phân tích các cơ chế phá hủy, nghiên cứu đã đưa ra phương pháp để dự đoán khả năng sinh cát trong tầng trầm tích mỏ $X$, bồn trũng Cửu Long.

[8]. J. Bellarby, Well Completion Design, Volume 56, Oxford,United Kingdom: Elsevier's Science \& Technology Department, 2009.

[9]. Ian Palmer (BP), Hans Vaziri (BP), Stephen Willson (BP), Zissis Moschovidis (PCM), John Cameron (PCM), Ion Ispas (BP), "Predicting and Managing Sand Production: A New Strategy," SPE 84499.

[10].Henry A. Ohen, Spe, Intrgrated Reservoir Solutions, Core Laborates, "Calibrated Wireline Mechanical Rock Properties Model for Predicting and Preventing Wellbore Collapse and Sanding," SPE 82236.

[11].H.H. Abass, SPE, A.H. Habbtar, SPE, A. Shebatalhamd, SPE, Saudi Aramco, "Sand Control during Drilling, Perforation, Completion and Production," SPE 814292.

[12].J. Bellarby, Well completion design, Aberdeen, 2009.

[13].Bellarby, Jonathan, Well Completion DesignVolume 56, 2009.

[14].Halliburton, Halliburton Sand Control.

[15].Michael Golan. Curtis H.Whitson, Well performance, second ed., 1996

\section{Trang 78}

